\title{
PERENCANAAN PENGELOLAAN KEUANGAN DESA (STUDI KASUS PADA DESA TEMBOKREJO KECAMATAN GUMUKMAS KABUPATEN JEMBER)
}

\author{
Putri Izatul Azwa Amalia ${ }^{1 "}$, Endro Sugiartono ${ }^{1}$ \\ ${ }^{1}$ Politeknik Negeri Jember, Jl. Mastrip No.164 Jember, Indonesia \\ "Korespondensi: izatulamalia09@gmail.com
}

\begin{abstract}
This study aims to explain the financial management planning of Tembokrejo Village, as well as analyze its suitability then provide an overview of the flowchart of village financial management planning according to Permendagri Number 20 of 2018. This research is a type of qualitative research with a case study approach using primary data and data. secondary data collection procedures, namely observation, interviews, and documentation. And the data analysis technique is a comparative analysis which tests the validity of the data using the triangulation technique. Then the activities in data analysis are data reduction, data presentation, and drawing conclusions and verification. The results of this study indicate that the financial management plan of Tembokrejo Village is in accordance with the village financial management plan according to Permendagri Number 20 of 2018, due to the presence of village assistants who help in the process of preparing village financial management planning. Therefore, a flowchart was designed, which could be used as a guide to assist village officials in the process of preparing village financial management plans independently.
\end{abstract}

Keywords: Planning, Management, Financial Village

\begin{abstract}
ABSTRAK
Penelitian ini bertujuan untuk menjelaskan perencanaan pengelolaan keuangan Desa Tembokrejo, serta menganalisis kesesuaiannya kemudian memberikan gambaran alur bagan proses (flowchart) perencanaan pengelolaan keuangan desa menurut Permendagri Nomor 20 Tahun 2018. Penelitian ini merupakan jenis penelitian kualitatif dengan pendekatan studi kasus yang menggunakan data primer dan data sekunder dengan prosedur pengumpulan data yaitu observasi, wawancara, dan dokumentasi. Serta dengan teknik analisis data adalah analisis komparatif yang uji keabsahan datanya menggunakan teknik triangulasi. Kemudian aktivitas dalam analisis data yaitu reduksi data, penyajian data, serta penarikan kesimpulan dan verifikasi. Hasil penelitian ini menunjukkan bahwa perencanaan pengelolaan keuangan Desa Tembokrejo sudah sesuai dengan perencanaan pengelolaan keuangan desa menurut Permendagri Nomor 20 Tahun 2018, dikarenakan adanya tenaga pendamping desa yang membantu dalam proses penyusunan perencanaan pengelolaan keuangan desa. Maka dari itu dirancangkan sebuah Alur Bagan Proses (flowchart), yang dapat digunakan sebagai pedoman untuk membantu perangkat desa dalam proses penyusunan perencanaan pengelolaan keuangan desa secara mandiri.
\end{abstract}

Kata kunci: Perencanaan, Pengelolaan, Keuangan Desa 


\section{PENDAHULUAN}

Perkembangan sistem pemerintahan yang ada di Indonesia semakin maju dan berkembang dengan pesat setelah memasuki masa reformasi (Yudha Pradana, 2018). Pada saat ini sistem desentralisasi yang diterapkan di pemerintahan Indonesia, bukan lagi menerapkan sistem sentralisasi. Sistem desentralisasi merupakan penyerahan wewenang dalam membuat, memutuskan dan melaksanakan kebijakan dari pemerintah pusat kepada pemerintah daerah untuk mengatur rumah tangganya sendiri. Tetapi tidak untuk semua hal, termasuk dengan keamanan, hukum, dan kebijakan fiskal masih terpusat, namun ada pendelegasian kepada daerah.

Undang-Undang Republik Indonesia Nomor 23 Tahun 2014 Tentang Pemerintahan Daerah menyebutkan bahwa Pemerintah Daerah adalah kepala daerah sebagai unsur penyelenggara Pemerintahan Daerah yang memimpin pelaksanaan urusan pemerintahan yang menjadi kewenangan daerah otonom. Kemudian pengertian Otonomi Daerah adalah hak, wewenang, dan kewajiban daerah otonom untuk mengatur dan mengurus sendiri urusan pemerintahan dan kepentingan masyarakat setempat dalam sistem Negara Kesatuan Republik Indonesia (NKRI). Kewenangan yang diterima daerah melalui adanya otonomi daerah akan memberikan kebebasan kepada daerah dalam hal membuat, memutuskan dan melaksanakan kebijakan yang diharapkan akan sesuai dengan kondisi serta aspirasi masyarakat di wilayahnya. Mengingat setiap daerah dapat lebih memahami kebutuhan masyarakatnya, maka otonomi daerah dapat terlaksana dengan baik dan terencana (Orangbio et al., 2017). Namun, kebijakan dalam mengambil keputusan untuk menjalankan otonomi daerah belum berjalan dengan semestinya, karena masih ada kesenjangan antara masyarakat desa dengan masyarakat kota akibat belum meratanya pembangunan dalam segala bidang. Berdasarkan hal tersebut, pemerintah membentuk otonomi desa, otonomi desa merupakan kewenangan untuk mengatur dan mengurus urusan rumah tangganya sendiri, yang hanya masyarakat desa yang bersangkutan boleh mengatur dan mengurus urusannya (Nurcholis, 2011). Kemudian menurut (Aji Atmaja, 2016), Orang-orang luar yang tidak berkepentingan tidak boleh ikut campur mengatur dan mengurus kepentingan masyarakat desa yang bersangkutan.

Program otonomi desa tersebut didukung oleh pemerintah pusat melalui bantuan berupa Dana Desa (DD) sebagai perwujudan dari sistem desentralisasi keuangan menuju desa mandiri. Menurut (Peraturan Pemerintah Republik Indonesia Nomor 60 Tahun 2014 Tentang Dana Desa Yang Bersumber Dari Anggaran Pendapatan Dan Belanja Negara, 2014) menerangkan bahwa Dana Desa (DD) adalah dana yang bersumber dari Anggaran Pendapatan dan Belanja Negara (APBN) yang diperuntukkan bagi Desa yang ditransfer melalui Anggaran Pendapatan dan Belanja Daerah (APBD) kabupaten/kota dan dapat digunakan untuk membiayai penyelenggaraan pemerintahan, pelaksanaan pembangunan, pembinaan kemasyarakatan, dan pemberdayaan masyarakat. Selain itu, salah satu sumber pendapatan desa yang berfungsi sebagai sumber kegiatan operasional desa dan untuk pemberdayaan masyarakat adalah Alokasi Dana Desa (ADD). Berdasarkan (Undang-Undang Republik Indonesia Nomor 6 Tahun 2014 Tentang Desa, 2014), Alokasi Dana Desa (ADD) diperoleh dari dana perimbangan yang diterima 
kabupaten/kota dalam Anggaran Pendapatan dan Belanja Daerah (APBD) setelah adanya pengurangan Dana Alokasi Khusus (DAK), Alokasi Dana Desa (ADD) diterima paling sedikit 10\% (sepuluh persen). Pemerintahan desa dalam mengurus urusan pemerintahannya serta kepentingan masyarakat, tentunya membutuhkan pemasukan atau pendapatan yang berguna untuk mencapai tujuan desa dalam hal pembangunan desa dan kesejahteraan desa (Walukow et al., 2017). Diterimanya dana bagi desa tersebut, membuat pemerintah desa harus selalu siap, juga mampu dalam mengelola keuangan desa, serta semakin terbuka dan bertanggung jawab terhadap proses pengelolaan keuangan desa. Oleh karena itu, perlu adanya pembinaan dan pengawasan terhadap pengelolaan keuangan desa.

Pengelolaan keuangan desa berdasarkan (Peraturan Menteri Dalam Negeri No 20 Tahun 2018 Tentang Pengelolaan Keuangan Desa, 2018) adalah keseluruhan kegiatan yang meliputi perencanaan, pelaksanaan, penatausahaan, pelaporan, dan pertanggungjawaban keuangan desa yang dilakukan oleh kepala desa (kades) selaku Pemegang Kekuasaan Pengelolaan Keuangan Desa (PKPKD) yang dibantu oleh Pelaksana Pengelolaan Keuangan Desa (PPKD). Untuk melaksanakan pengelolaan keuangan desa ini harus dilaksanakan secara hati-hati serta harus berdasarkan peraturan yang telah ditetapkan (Mamuaya et al., 2017).

Perencanaan menjadi sangat penting dalam pelaksanaan kegiatan pembangunan desa dan juga sebagai langkah awal dalam proses pengelolaan keuangan desa. Perencanaan (planning) adalah sebuah proses dimulai dari penetapan tujuan organisasi, penentuan strategi untuk mencapai tujuan organisasi tersebut secara menyeluruh, perumusan sistem perencanaan yang menyeluruh untuk mengintegrasikan dan mengkoordinasikan seluruh pekerjaan organisasi, sehingga pencapaian tujuan organisasi (Bastian, 2015). Dari aspirasi masyarakat, kebutuhan masyarakat, potensi dan masalah yang dihadapi oleh masyarakat desa merupakan acuan yang harus digunakan sebelum dilaksanakannya pembangunan desa tersebut, baik dalam pembangunan fisik maupun pembangunan non fisik desa. Badan Permusyawaratan Desa (BPD), dan pemerintah desa yang melibatkan unsur masyarakat desa harus melakukan musyawarah mengenai hal-hal yang menjadi program desa dalam hal pembangunan. Seluruh kegiatan musyawarah dilaksanakan paling sedikit satu kali dalam satu tahun dengan tujuan dapat meminimalisir timbulnya pertentangan dan konflik antara masyarakat dengan pemerintah desa.

Penelitian ini membahas mengenai langkah awal atau proses awal dalam pengelolaan keuangan desa yaitu perencanaan pengelolaan keuangan desa, dimana perencanaan menjadi poin penting dalam hal pengelolaan keuangan desa (Fitriani et al., 2017). Dimana perencanaan merupakan tahap pertama dalam pengelolaan keuangan desa dan merupakan langkah awal dalam proses manajemen, yang di maksud adalah merencanakan kegiatan yang akan dijalankan dalam pemerintahan desa untuk mencapai tujuan desa. Pemilihan perencanaan pengelolaan keuangan desa pada penelitian ini dikarenakan ingin mengetahui lebih jelas bagaimana proses perencanaan pengelolaan keuangan desa serta menganalisa bagaimana desa dapat merancang penyusunan Anggaran Pendapatan dan Belanja Desa (APBDes) dengan baik dan benar. Kemudian juga ingin meneliti apakah pemerintah desa sudah menjalankan perencanaan pengelolaan keuangan desa sesuai dengan (Peraturan 
Menteri Dalam Negeri No 20 Tahun 2018 Tentang Pengelolaan Keuangan Desa, 2018) serta sejauh mana pemerintah desa dalam menaati dasar hukum tersebut.

Penelitian ini memilih objek penelitian di Desa Tembokrejo karena sampai sejauh ini belum pernah terlambat dalam melaporkan keuangannya. Pada dasarnya, jika tidak ada keterlambatan dalam melaporkan keuangan desa, dapat dikatakan bahwa Desa Tembokrejo telah merencanakan pengelolaan keuangan desa dengan baik dan sesuai dengan (Peraturan Menteri Dalam Negeri No 20 Tahun 2018 Tentang Pengelolaan Keuangan Desa, 2018), namun ada kendala pada perangkat desanya dalam melaksanakan proses penyusunan perencanaan pengelolaan keuangan desa tersebut. Alasan dalam memilih objek penelitian di Desa Tembokrejo karena kurang fahamnya perangkat desa dengan dasar hukum yang digunakan dalam proses perencanaan pengelolaan keuangan desa. Dibuktikan dengan keberadaan tenaga pendamping desa yang sering kali dijadikan tumpuan bagi perangkat desa dalam proses penyusunan perencanaan pengelolaan keuangan desa, sehingga perangkat desa kurang detail dalam melakukan proses penyusunan perencanaan pengelolaan keuangan desa. Adanya tenaga pendamping desa yang berdasarkan (Peraturan Pemerintah Republik Indonesia Nomor 47 Tahun 2015 Tentang Perubahan Atas Peraturan Pemerintah Nomor 43 Tahun 2014 Tentang Peraturan Pelaksanaan Undang-Undang Nomor 6 Tahun 2014 Tentang Desa, 2015), yang ditunjuk oleh kecamatan pada saat dilaksanakannya proses perencanaan pengelolaan keuangan desa.

\section{METODE PENELITIAN}

Metode penelitian yang digunakan dalam penelitian ini adalah penelitian kualitatif. Menurut (Sugiyono, 2017), Penelitian kualitatif adalah metode penelitian yang didasarkan pada filsafat postpositivisme yang dapat digunakan untuk mempelajari keadaan alami suatu objek (sebagai lawan dari eksperimen), kemudian apabila peneliti adalah alat kunci, metode pengumpulan data dapat ditriangulasi, analisis datanya bersifat induktif/kualitatif, dan hasil penelitian kualitatif menekankan makna dari pada generalisasi. Penelitian kualitatif terdapat berbagai macam penelitian yang dapat digunakan, dalam penelitian ini mengambil penelitian studi kasus. Menurut (Fatchan, 2011), Penelitian yang dilakukan untuk tujuan eksplorasi sangat erat kaitannya dengan interaksi dengan lingkungan dan lokasi pada objek penelitian (misalnya individu, komunitas, atau institusi) merupakan penelitian studi kasus.

Informan pada penelitian ini terdiri dari sembilan orang, yaitu : kepala desa (kades), sekretaris desa (sekdes), bendahara desa, Badan Permusyawaratan Desa (BPD), kaur tata usaha \& umum, kaur perencanaan, kasi pemerintahan, kasi kesejahteraan, dan kasi pelayanan. Data yang digunakan merupakan data primer dan data sekunder. Menurut (Sanusi, 2011), data primer merupakan data mentah yang pertama kali diterima peneliti, kemudian dicatat dan dikumpulkan. Sedangkan Data Sekunder merupakan data yang diperoleh secara tidak langsung dengan menggunakan media perantara dan/atau dari sumber yang sudah ada. Prosedur pengumpulan data pada penelitian ini yaitu observasi, Observasi atau pengamatan adalah kegiatan untuk melakukan pengamatan terhadap fenomena atau kasus yang diteliti, yang dapat dilakukan secara sistematis (Mirnawati, 2017). Observasi inilah yang menghasilkan berupa catatan atau rekaman atas suatu kejadian, yang kemudian mengarah pada apa yang akan menjadi masalah dan fokus penelitian yang akan dilakukan. Kemudian ada wawancara, Menurut (Fatchan, 2011) wawancara merupakan salah satu pengambilan data yang dilakukan melalui kegiatan komunikasi lisan dalam bentuk terstruktur, semi terstruktur, dan tak terstruktur. Wawancara dilakukan dengan alat bantu berupa kuisioner tertutup yang merupakan daftar pertanyaan wawancara. Yang terakhir yaitu dokumentasi, 
dimana dokumentasi ini berupa dokumen-dokumen yang berhubungan dengan perencanaan pengelolaan keuangan desa di Desa Tembokrejo. Menurut (Sanusi, 2011), untuk mengumpulkan data sekunder yang mencakup berbagai sumber, biasanya dapat dilakukan dengan cara dokumentasi, baik secara pribadi maupun kelembagaan. Dokumen yang diperlukan dalam menganalisis penelitian ini adalah Anggaran Pendapatan dan Belanja Desa (APBDes), Rencana Pembangunan Jangka Menengah (RPJMDes), dan Rencana Kerja Pembangunan Desa (RKPDes).

Kemudian teknik analisis data yang digunakan adalah analisis komparatif, dimana pada penelitian ini analisis komparatif dilakukan pada perencanaan pengelolaan keuangan desa di Desa Tembokrejo dengan perencanaan pengelolaan keuangan desa menurut Peraturan Menteri Dalam Negeri (Permendagri) Nomor 20 tahun 2018 tentang Pedoman Pengelolaan Keuangan Desa. Perlu dilakukan adanya upaya pemeriksaan keabsahan data agar dapat menentukan sahih/validnya suatu data. Upaya pemeriksaan keabsahan data merupakan suatu cara untuk menanggulangi keraguan tentang keabsahan data tersebut. Menurut (Sugiyono, 2017), terdapat empat macam bentuk pengujian keabsahan data dalam penelitian kualitatif, meliputi : uji kredibilitas (validitas internal), transferability (validitas eksternal), dependability (reliabilitas), dan confirmability (obyektivitas). Kemudian data tersebut di uji keabsahan datanya menggunakan teknik triangulasi yang sekaligus menguji kedibilitas data. Pada penelitian ini, pengujian kredibilitas data dapat dicapai melalui :

a. Membandingkan data hasil observasi dengan data hasil wawancara dari sembilan informan tersebut.

b. Membandingkan hasil wawancara informan satu dengan informan yang lain agar dapat mengetahui bahwa data yang disampaikan merupakan data yang benar.

Teknik pengumpulan data yang dapat menggabungkan sebuah data dari berbagai pengumpulan data dan sumber data yang telah ada disebut sebagai triangulasi (Sugiyono, 2017). Teknik triangulasi dalam pengujian kredibilitas data dapat diartikan sebagai pengecekan data dari berbagai sumber, berbagai cara (teknik), dan dengan berbagai waktu. Teknik analisis data menggunakan Model Miles dan Huberman (1984) dalam (Sugiyono, 2017), dikatakan bahwa kegiatan yang terjadi dalam analisis data kualitatif dapat dilakukan secara interaktif, dan dapat dilakukan terus menerus hingga selesai, sehingga data yang diperoleh sudah jenuh. Aktivitas dalam analisis data, yaitu : data reduction (reduksi data), data display (Penyajian Data), dan conclusing drawing/verification (penarikan kesimpulan dan verifikasi).

\section{HASIL DAN PEMBAHASAN}

\section{Perencanaan Pengelolaan Keuangan Desa Tembokrejo}

Proses awal penyusunan perencanaan pengelolaan keuangan desa diawali dari Musyawarah Dusun (musdus) yang dilaksanakan pada Bulan Januari. Kemudian pada bulan selanjutnya yaitu Bulan Februari, untuk menindaklanjuti Musyawarah Dusun (musdus) tersebut, Desa Tembokrejo melaksanakan Musyawarah Desa (musdes). Hasil dari Musyawarah Desa (musdes) inilah yang dijadikan dasar dalam penyusunan rancangan Rencana Pembangunan Jangka Menengah Desa (RPJMDes) yang dibahas dalam forum Musyawarah Rencana Pembangunan Desa (Musrenbangdes) dan dilaksanakan pada Bulan Maret sampai dengan awal Bulan April.

Hasil dari Musyawarah Rencana Pembangunan Desa (Musrenbangdes) ini yang akan dijadikan dasar dalam penyusunan Rencana Pembangunan Jangka Menengah Desa (RPJMDes) pada Bulan Mei sampai dengan Bulan Juni. Bersamaan dengan hal 
itu, di buatlah rancangan Rencana Kerja Pembangunan Desa (RKPDes) dan membentuk tim penyusun Rencana Kerja Pembangunan Desa (RKPDes). Penyusunan Rencana Kerja Pembangunan Desa (RKPDes) dilaksanakan pada Bulan Juli sampai dengan Bulan September yang digunakan sebagai dasar penyusunan peraturan desa tentang Anggaran Pendapatan dan Belanja Desa (APBDesa) dan sebagai pedoman dalam kegiatan pelaksanaan pembangunan desa pada setiap tahun. Memasuki tahap penyusunan Anggaran Pendapatan dan Belanja Desa (APBDes) sampai dengan menyusun peraturan desa tentang Anggaran Pendapatan dan Belanja Desa (APBDes) yang penetapannya paling lambat Bulan Desember. Maka proses penyusunan perencanaan pengelolaan keuangan desa pada Desa Tembokrejo telah selesai dilaksanakan.

Secara garis besar perencanaan pengelolaan keuangan desa pada Desa Tembokrejo mulai dari disusunnya Rencana Pembangunan Jangka Menengah Desa (RPJMDes) sampai dengan terbentuknya Anggaran Pendapatan dan Belanja Desa (APBDes) adalah sebagai berikut :

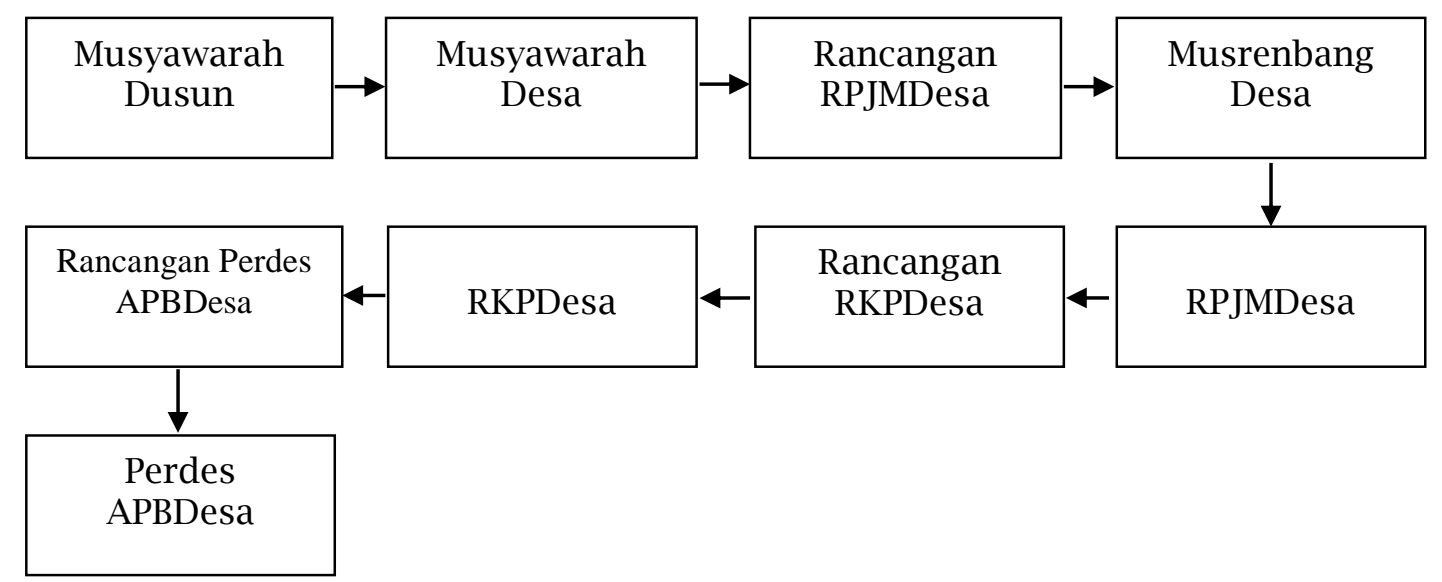

Gambar 1. Perencanaan Pengelolaan Keuangan Desa pada Desa Tembokrejo

Seluruh rangkaian proses perencanaan pengelolaan keuangan desa di Desa Tembokrejo tentunya ada tenaga pendamping desa yang ditunjuk oleh kecamatan untuk membimbing serta mengawasi para perangkat desa dalam proses penyusunan tersebut agar sesuai dengan dasar hukum yang digunakan yaitu Peraturan Menteri Dalam Negeri (Permendagri) Nomor 20 Tahun 2018. Keberadaan tenaga pendamping desa sering kali dijadikan tumpuan bagi perangkat desa dalam proses penyusunan perencanaan pengelolaan keuangan desa, sehingga perangkat desa kurang detail dalam melakukan proses penyusunan perencanaan pengelolaan keuangan desa tersebut sebagaimana yang telah ditentukan dalam Peraturan Menteri Dalam Negeri (Permendagri) Nomor 20 Tahun 2018.

\section{Kesesuaian antara Perencanaan Pengelolaan Keuangan Desa Tembokrejo dengan Perencanaan Pengelolaan Keuangan Desa menurut Peraturan Menteri Dalam Negeri (Permendagri) Nomor 20 Tahun 2018}

Secara keseluruhan proses perencanaan pengelolaan keuangan desa di Desa Tembokrejo sudah sesuai dengan perencanaan pengelolaan keuangan desa yang ada pada Peraturan Menteri Dalam Negeri (Permendagri) Nomor 20 Tahun 2018. Hal tersebut ditunjukkan dengan adanya presentase sebesar 92\% sesuai dengan dasar hukum yang berlaku. Kemudian ada presentase sebesar $8 \%$ tidak sesuai. Berikut merupakan presentase jawaban yang sudah diberikan oleh informan, yaitu :

1. Jawaban "Ya"

$$
\frac{198}{216} \times 100 \%=92 \%
$$


2. Jawaban "Tidak"

$\frac{18}{216} \times 100 \%=8 \%$

Kesesuaian yang ditunjukkan dengan presentase sebesar 92\% ini menunjukkan bahwa dalam proses penyusunan perencanaan pengelolaan keuangan desa selalu didampingi oleh pendamping desa dari kecamatan. Kemudian terdapat 8\% ketidaksesuaian pada saat proses penyusunan perencanaan pengelolaan keuangan desa di Desa Tembokrejo. Hal tersebut dikarenakan perangkat desa tidak mengetahui atau tidak memahami dasar hukum yang digunakan dalam proses penyusunan perencanaan pengelolaan keuangan desa. Ketidakfahaman ini membuat proses penyusunan perencanaan pengelolaan keuangan desa menjadi terhambat karena tidak dapat dilakukan secara mandiri atau harus menunnggu adanya tenaga pendamping.

Mempelajari dasar hukum yang digunakan akan bermanfaat dalam proses penyusunan perencanaan pengelolaan keuangan desa, karena jika pendamping desa berhalangan hadir perangkat desa dapat menyusun perencanaan pengelolaan keuangan desa secara mandiri, yang kemudian dapat dibahas lagi ketika sudah ada pendamping desa. Maka dari itu dibutuhkan kehandalan Sumber Daya Manusia (SDM) dari perangkat desa yang mampu memahami atau menguasai terkait dasar hukum yang digunakan dalam pengelolaan keuangan desa. Agar seluruh proses pengelolaan keuangan desa dapat berjalan dengan baik dan sesuai dengan dasar hukum yang digunakan. Kehandalan Sumber Daya Manusia (SDM) dapat di asah dengan cara mengikuti seminar, pelatihan ataupun diklat yang diselenggarakan oleh pihak kecamatan ataupun kabupaten, agar terus mengikuti pembaruan yang ada.

\section{Gambaran Alur Bagan Proses (flowchart) Perencanaan Pengelolaan Keuangan Desa yang Sesuai Menurut Peraturan Menteri Dalam Negeri (Permendagri) Nomor 20 Tahun 2018}

Berdasarkan dari pemaparan diatas yang menunjukkan presentase jawaban $8 \%$ yang ditanyakan kepada informan, menunjukkan bahwa perencanaan pengelolaan keuangan desa bisa dihasilkan dengan baik dan sesuai dengan dasar hukum yang digunakan karena adanya tenaga pendamping desa dari kecamatan. Maka dipandang perlu untuk dirancangkan sebuah Alur Bagan Proses (flowchart) yang merupakan suatu simbol yang dapat menggambarkan urutan sebuah proses secara detail dan saling berhubungan antara suatu proses dengan proses yang lainnya dalam suatu kegiatan/program.

Adanya gambar alur bagan proses (flowchart) pada gambar 2 dapat membantu proses penyusunan perencaan pengelolaan keuangan desa di Desa Tembokrejo yang sesuai dengan Peraturan Menteri Dalam Negeri (Permendagri) Nomor 20 Tahun 2018 tentang pengelolaan keuangan desa. Alur bagan proses (flowchart) ini menjelaskan secara rinci dan runtut, sehingga dapat mempermudah perangkat desa dalam melaksanakan penyusunan perencanaan pengelolaan keuangan desa.

Berikut merupakan Alur Bagan Proses (flowchart) Perencanaan Pengelolaan Keuangan Desa yang sesuai menurut Peraturan Menteri Dalam Negeri (Permendagri) Nomor 20 Tahun 2018 : 


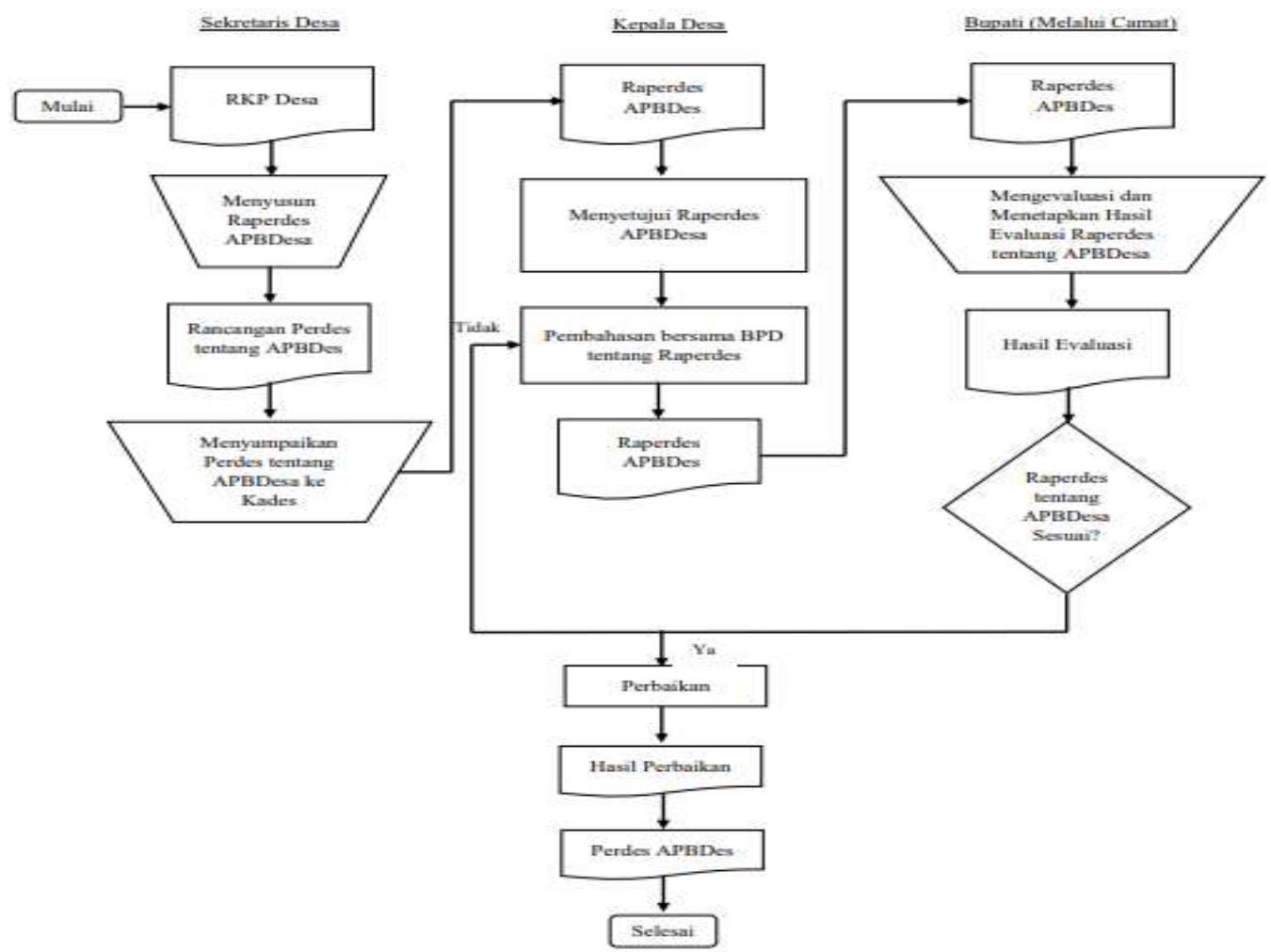

Gambar 2. Alur Bagan Proses (flowchart) Perencanaan Pengelolaan Keuangan Desa berdasarkan Permendagri Nomor 20 Tahun 2018

\section{SIMPULAN}

Perencanaan pengelolaan keuangan desa di Desa Tembokrejo sudah berjalan dengan baik, dan sudah mengikuti dasar hukum yang digunakan. Artinya proses penyusunan perencanaan pengelolaan keuangan desa sudah sesuai dengan Peraturan Menteri Dalam Negeri (Permendagri) Nomor 20 Tahun 2018. Tetapi seluruh kegiatan perencanaan pengelolaan keuangan desa, Desa Tembokrejo didampingi oleh pendamping desa dari kecamatan. Hal ini dikarenakan lemahnya pemahaman perangkat desa atas dasar hukum yang digunakan dalam proses perencanaan pengelolaan keuangan desa, sehingga kurang detail jika dilakukan secara mandiri. Maka dari itu, dirancangkan sebuah alur bagan proses (flowchart) yang dapat mempermudah perangkat desa dalam proses penyusunan perencanaan pengelolaan keuangan desa secara mandiri karena dapat dijadikan sebagai pedoman yang sesuai dengan Peraturan Menteri Dalam Negeri (Permendagri) Nomor 20 Tahun 2018.

Keterbatasan pada penelitian ini adalah tidak membahas seluruh kegiatan pengelolaan keuangan desa karena memang kasus yang ditemukan hanya terbatas pada perencanaan pengelolaan keuangan desa saja. Saran bagi peneliti selanjutnya agar membahas keseluruhan kegiatan pengelolaan keuangan desa dan dapat memperbarui dasar hukum yang digunakan sebagai acuan.

\section{DAFTAR RUJUKAN}

Aji Atmaja, D. (2016). Analisis Pengelolaan Keuangan dan Kekayaan Desa (Studi Kasus di Desa Plesungan Kecamatan Gondangrejo Kabupaten Karanganyar). Jurnal Akuntansi Bisnis Eka Prasetya: Penelitian Ilmu Akuntansi, 6(1), 1-14. https://doi.org/10.47663/abep.v6i1.55 
Bastian, I. (2015). Akuntansi Untuk Kecamatan dan Desa. Erlangga.

Fatchan, H. A. (2011). Metode Penelitian Kualitatif.

Fitriani, W. D., Susyanti, J., \& Khoirul ABS, M. (2017). Analisis Perencanaan Pengelolaan Keuangan Desa Menurut Peraturan Menteri Dalam Negeri Nomor 113 Tahun 2014 (Studi Kasus di Desa Masangan Wetan Kecamatan Sukodono Kabupaten Sidoarjo Periode 2017). E-Jurnal Riset Manajemen, 46-57.

Peraturan Pemerintah Republik Indonesia Nomor 60 Tahun 2014 tentang Dana Desa yang Bersumber dari Anggaran Pendapatan dan Belanja Negara, 18 (2014).

Undang-Undang Republik Indonesia Nomor 23 Tahun 2014 tentang Pemerintahan Daerah, 203 (2014).

Undang-Undang Republik Indonesia Nomor 6 Tahun 2014 tentang Desa, 18-April-2 45 (2014). https://doi.org/10.1145/2904081.2904088

Peraturan Pemerintah Republik Indonesia Nomor 47 Tahun 2015 tentang Perubahan Atas Peraturan Pemerintah Nomor 43 Tahun 2014 tentang Peraturan Pelaksanaan Undang-Undang Nomor 6 Tahun 2014 tentang Desa, (2015).

Mamuaya, J. V., Sabijono, H., \& Gamaliel, H. (2017). Analisis Pengelolaan Keuangan Desa Berdasarkan Permendagri No. 113 Tahun 2014 (Studi Kasus di Desa Adow Kecamatan Pinolosian Tengah Kabupaten Bolaang Mongondow Selatan). Riset Ekonomi, Manajemen, Bisnis Dan Akuntansi, 5(2), 1020-1030.

Peraturan Menteri Dalam Negeri No 20 Tahun 2018 Tentang Pengelolaan Keuangan Desa, 721 (2018).

Mirnawati, I. (2017). Analisis Pengelolaan Keuangan Desa Berdasarkan Peraturan Menteri Dalam Negeri Nomor 113 Tahun 2014 (Studi Kasus pada Desa di Kecamatan Tanjung Raja Kabupaten Ogan Ilir) (Vol. 53, Issue 4).

Nurcholis, H. (2011). Pertumbuhan \& Penyelenggaraan Pemerintahan Desa.

Orangbio, V. V., Tinangon, J. J., \& Gerungai, N. (2017). Analisis Perencanaan dan Pertanggungjawaban APBDes Menurut Peraturan Menteri Dalam Negeri Nomor 113 Tahun2014 dalam Upaya Meningkatkan Pembangunan Desa. Going Concern: Jurnal Riset Akuntansi, 12(2), 53-60. https://doi.org/10.32400/gc.12.2.17389.2017

Sanusi, A. (2011). Metodologi Penelitian Bisnis.

Sugiyono. (2017). Metode Penelitian Kuabtitatif, Kualitatif, dan R\&D.

Walukow, M. I., Kalangi, L., \& Pinatik, S. (2017). Analisis Perencanaan Pengelolaan Keuangan Desa Sesuai Dengan Peraturan Menteri Dalam Negeri Nomor 113 Tahun 2014 Di Desa Kauneran I Kecamatan Sonder Kabupaten Minahasa. Going Concern: Jurnal Riset Akuntansi, 12(2), 266-275. https://doi.org/10.32400/gc.12.2.17616.2017

Yudha Pradana, H. (2018). Analisis Penerapan Pengelolaan Keuangan Desa Berdasarkan Peraturan Menteri Dalam Negeri Nomor 113 Tahun 2014 (Studi Kasus di Desa Jatimulyo Kecamatan Girimulyo Kabupaten Kulon Progo) (Vol. 151, Issue 2). 